\title{
Actinomadura bangladeshensis sp. nov. and Actinomadura chokoriensis sp. nov.
}

\author{
Correspondence \\ Yoko Takahashi \\ ytakaha@lisci.kitasato-u.ac.jp
}

\author{
Ismet Ara, ${ }^{1}$ Atsuko Matsumoto, ${ }^{2}$ Mohammad Abdul Bakir, ${ }^{3}$ Takuji Kudo, ${ }^{3}$ \\ Satoshi Ōmura ${ }^{1,2}$ and Yoko Takahashi ${ }^{1}$
}

\author{
${ }^{1}$ Kitasato Institute for Life Sciences, Kitasato University, 5-9-1 Shirokane, Minato-ku, Tokyo \\ 108-8641, Japan \\ ${ }^{2}$ The Kitasato Institute, 5-9-1 Shirokane, Minato-ku, Tokyo 108-8642, Japan \\ ${ }^{3}$ Microbe Division/Japan Collection of Microorganisms, RIKEN BioResource Center, 2-1 Hirosawa, \\ Wako, Saitama 351-0198, Japan
}

\begin{abstract}
The taxonomic position of two soil isolates, $3-46-\mathrm{b}(3)^{\top}$ and $3-45-\mathrm{a}(11)^{\top}$, was clarified based on data from a polyphasic study. The organisms showed a combination of chemotaxonomic and morphological properties typical of the genus Actinomadura. They formed distinct phyletic lines in the Actinomadura 16S rRNA gene tree and were closely associated with the type strains of Actinomadura meyerae (sequence similarity of 98.3-98.5\%), Actinomadura napierensis (98.198.3\%) and Actinomadura latina (96.4-96.8\%). The level of 16S rRNA gene sequence similarity between the new isolates was $99.1 \%$. The level of DNA-DNA hybridization between strains $3-46-b(3)^{\top}$ and $3-45-a(11)^{\top}$ was $43.6 \%$ and levels of relatedness between the two new isolates and the type strains of $A$. meyerae and $A$. napierensis were 21.0-27.3\%. On the basis of phenotypic and genotypic properties, the new isolates could be differentiated from each other and from their closest phylogenetic relatives. It is proposed that the organisms be classified as representing two novel species of the genus Actinomadura. The names proposed for these taxa are Actinomadura bangladeshensis sp. nov. [type strain $3-46-b(3)^{\top}=\mathrm{JCM} 13933^{\top}$

$=\mathrm{MTCC}_{0057^{\top}}$ ] and Actinomadura chokoriensis sp. nov. [type strain 3-45-a(11) ${ }^{\top}=\mathrm{JCM} 13932^{\top}$ $=$ MTCC $\left.8056^{\mathrm{T}}\right]$.
\end{abstract}

The application of chemosystematic, numerical phenetic and molecular systematic methods has clarified the taxonomy of the genus Actinomadura and related taxa (Poscher et al., 1985; Kroppenstedt et al., 1990; Ochi et al., 1991; Trujillo \& Goodfellow, 1997, 2003; Quintana et al., 2003a; Lee \& Jeong, 2006; Le Roes \& Meyers, 2007). The genus Actinomadura belongs to the family Thermomonosporaceae Stackebrandt et al. 1997 emend. Zhang et al. 2001, which also includes the genera Actinocorallia (Iinuma et al., 1994; Zhang et al., 2001; Lee, 2006), Spirillospora (Couch, 1963) and Thermomonospora (Henssen, 1957; Zhang et al., 2001). Members of these genera form distinct phyletic lines in

Abbreviations: DAP, diaminopimelic acid; TBSA, tuberculostearic acid. The GenBank/EMBL/DDBJ accession numbers for the $16 \mathrm{~S}$ rRNA gene sequences of strains $3-46-b(3)^{\top}$ and $3-45-a(11)^{\top}$ are $A B 331652$ and AB331730, respectively.

A neighbour-joining tree based on nearly-complete $16 S$ rRNA gene sequences showing the relationships between strains $3-46-b(3)^{\top}, 3-45-$ $\mathrm{a}(11)^{\top}$ and the type strains of all recognized species of the genus Actinomadura is available as supplementary material with the online version of this paper. trees based on 16S rRNA gene sequences (Zhang et al., 1998, 2001) and can be distinguished from one another by using a combination of biochemical, chemical, morphological and physiological features (Zhang et al., 1998, 2001; Trujillo \& Goodfellow, 2003). At the time of writing, the genus Actinomadura encompasses 37 recognized species, which can be delineated based on a combination of genotypic and phenotypic data (Kroppenstedt \& Goodfellow, 1991; Zhang et al., 2001; Lu et al., 2003; Lee \& Jeong, 2006; Le Roes \& Meyers, 2007).

As part of a screening programme for antibiotic-producing actinomycetes, strains $3-46-\mathrm{b}(3)^{\mathrm{T}}$ and $3-45-\mathrm{a}(11)^{\mathrm{T}}$ were isolated from sandy soil collected at Chokoria, Cox's Bazar, Bangladesh. The two strains showed morphological characteristics typical of the genera Actinomadura and Nonomuraea. Here we describe the characterization and classification of these strains and propose that they represent two novel species of the genus Actinomadura.

Bacterial strains were isolated by using the standard dilution plate method and were grown on humic acid-vitamin agar (Hayakawa \& Nonomura, 1987) supplemented with cycloheximide $\left(50 \mathrm{mg} \mathrm{l}^{-1}\right)$, nystatin $\left(50 \mathrm{mg} \mathrm{l}^{-1}\right)$ and 
nalidixic acid (20 $\left.\mathrm{mg} \mathrm{l}^{-1}\right)$. After 21 days aerobic incubation at $30{ }^{\circ} \mathrm{C}$, the strains were transferred and purified on yeast extract-malt extract agar [medium 2 of the International Streptomyces Project (ISP); Shirling \& Gottlieb, 1966] and maintained as working cultures on Seino (yeast extractstarch) agar containing $15.0 \mathrm{~g}$ soluble starch, $4.0 \mathrm{~g}$ yeast extract, $0.5 \mathrm{~g} \mathrm{~K}_{2} \mathrm{HPO}_{4}, 0.5 \mathrm{~g} \mathrm{MgSO}_{4} \cdot 7 \mathrm{H}_{2} \mathrm{O}$ and $15.0 \mathrm{~g}$ agar per litre distilled water ( $\mathrm{pH}$ 7.2). For comparative purposes, Actinomadura napierensis JCM $13850^{\mathrm{T}}$ and Actinomadura meyerae JCM $13237^{\mathrm{T}}$ were used.

Strains $3-46-\mathrm{b}(3)^{\mathrm{T}}$ and $3-45-\mathrm{a}(11)^{\mathrm{T}}$ were grown on ISP medium 3 agar and ISP medium 2 agar at $30{ }^{\circ} \mathrm{C}$ for 21 days and then observed by light and scanning electron microscopy (model S-2400; Hitachi and model JSM-5600; JEOL). Samples for scanning electron microscopy were prepared as described by Itoh et al. (1989).

Phenotypic properties were examined by using the following standard methods. For cultural characterization, the isolates were grown for 21 days at $30{ }^{\circ} \mathrm{C}$ on various agar media as described by Waksman (1950, 1961), Shirling \& Gottlieb (1966) and Asano \& Kawamoto (1986). Names and designations of colony colour were based on Jacobson et al. (1958). The temperature range and $\mathrm{NaCl}$ tolerance for growth were determined on ISP medium 3 (Shirling \& Gottlieb, 1966). Utilization of carbohydrates (each at $1 \%$ ) as sole carbon sources was tested by using ISP medium 9 according to a modification of the method of Stevenson (1967). Production of melanoid pigments was examined by using tyrosine agar (ISP medium 7).

Freeze-dried cells that were used for chemotaxonomic analyses were obtained from cultures grown in yeastglucose (YD) or trypticase soy broth (TSB) on a rotary shaker for 2 weeks at $28{ }^{\circ} \mathrm{C}$. The isomer of diaminopimelic acid (DAP) was determined by using TLC as described by Staneck \& Roberts (1974). Reducing sugars in whole-cell hydrolysates were analysed by the paper chromatography method of Becker et al. (1965). The $N$-acyl group of muramic acid in the peptidoglycan was determined according to the method of Uchida \& Aida (1984). Phospholipids were extracted and identified by the method of Minnikin et al. (1984). Methyl esters of cellular fatty acids were analysed by TechnoSuruga Co., Ltd according to the instructions of the Microbial Identification System (MIDI) by using a gas chromatograph (model HP6890; Hewlett Packard) (Sasser, 1990). Isoprenoid quinones were extracted according to the method of Collins et al. (1977, 1984) and were analysed in an HPLC system (model 802SC; Jasco) equipped with a CAPCELL PAK C18 column (Shiseido) (Tamaoka et al., 1983). Preparation and detection of methyl esters of mycolic acids were carried out as described by Tomiyasu (1982). The G $+C$ content of the DNA was determined by using the HPLC method of Tamaoka \& Komagata (1984). An equimolar mixture of nucleotides was digested by bacterial alkaline phosphatase and used as the qualitative standard.
Chromosomal DNA of strains $3-46-\mathrm{b}(3)^{\mathrm{T}}$ and $3-45-\mathrm{a}(11)^{\mathrm{T}}$ was isolated from biomass. Cells were freeze-dried and mechanically ground as described by Raeder \& Broda (1985). Levels of DNA-DNA relatedness were measured fluorometrically by using the microplate hybridization method (Ezaki et al., 1989). Hybridization was carried out overnight at $54{ }^{\circ} \mathrm{C}$. Genomic DNA extraction, PCRmediated amplification of the 16S rRNA gene and sequencing of the PCR products were carried out as described by Nakajima et al. (1999) and Ara \& Kudo (2006, $2007 \mathrm{a}, \mathrm{b}, \mathrm{c}, \mathrm{d})$. The sequences were multiply aligned with selected sequences obtained from the GenBank/EMBL/ DDBJ databases by using the CLUSTAL_X program (Thompson et al., 1997). The alignment was manually verified and adjusted prior to tree construction. A phylogenetic tree was constructed according to the neighbour-joining method (Saitou \& Nei, 1987) contained in the CLUSTAL_X program, based on a comparison of $1241 \mathrm{nt}$ present in all the strains as a result of elimination of gaps and ambiguous nucleotides from the sequences between positions 34 and 1491 (numbering according to the Escherichia coli 16S rRNA gene sequence). Streptosporangium album NBRC $13900^{\mathrm{T}}$ was used as an outgroup. The confidence values of branches of the phylogenetic tree were determined by using bootstrap analyses based on 1000 resamplings (Felsenstein, 1985). Levels of 16S rRNA gene sequence similarity among

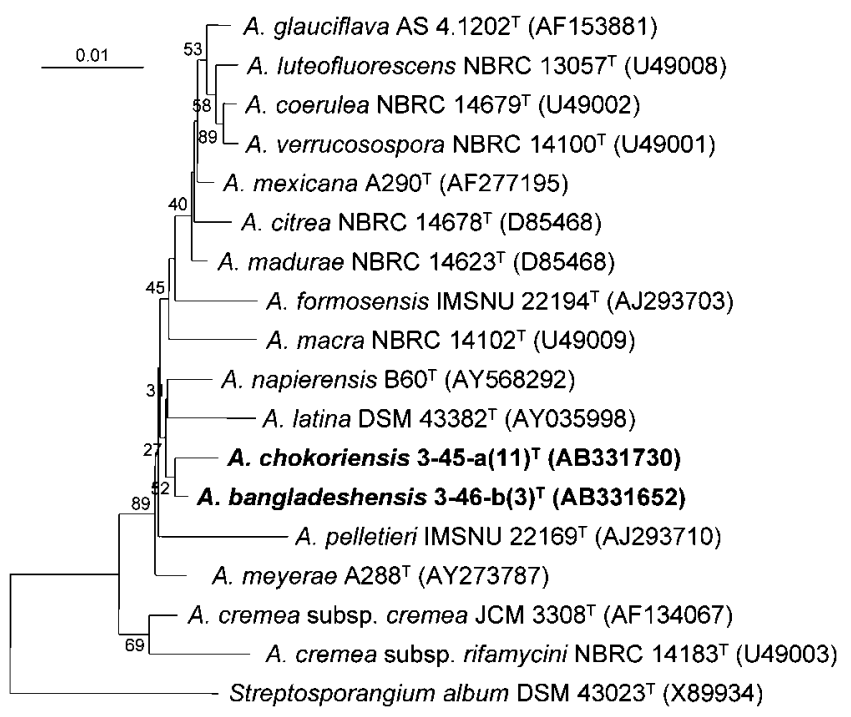

Fig. 1. Neighbour-joining tree based on nearly-complete $16 \mathrm{~S}$ rRNA gene sequences showing the relationship between strains $3-46-b(3)^{\top}$ and $3-45-a(11)^{\top}$ and the type strains of closely related species of the genus Actinomadura in the family Thermomonosporaceae. Streptosporangium album DSM $43023^{\top}$ was used as an outgroup. Numbers at nodes indicate levels of bootstrap support (\%) based on a neighbour-joining analysis of 1000 resampled datasets; only values above $20 \%$ are shown. Bar, 0.01 substitutions per site. A more complete version of this tree is available as Supplementary Fig. S1. 
Actinomadura strains were calculated manually after pairwise alignment with the CLUSTAL_X package.

Almost-complete 16S rRNA gene sequences for strains $3-46-b(3)^{\mathrm{T}} \quad(1497 \mathrm{nt})$ and $3-45-\mathrm{a}(11)^{\mathrm{T}} \quad(1501 \mathrm{nt})$ were determined in this study and were compared with corresponding sequences of all recognized species within the genus Actinomadura and related taxa in the family Thermomonosporaceae Stackebrandt et al. 1997 emend. Zhang et al. 2001. A neighbour-joining tree (Fig. 1; see also Supplementary Fig. S1 in IJSEM Online) based on $16 \mathrm{~S}$ rRNA gene sequences showed that the new isolates fell within the evolutionary radiation occupied by representatives of the genus Actinomadura. This generic assignment was supported by the results of our own and previous chemotaxonomic observations (Trujillo \& Goodfellow, 2003; Lee \& Jeong, 2006). Strains 3-46-b(3) ${ }^{\mathrm{T}}$ and 3-45$\mathrm{a}(11)^{\mathrm{T}}$ contained meso-DAP, madurose, galactose, glucose, ribose and mannose in whole-organism hydrolysates (wall chemotype IIIB sensu Lechevalier \& Lechevalier, 1970). Diagnostic phospholipids were phosphatidylglycerol and phosphatidylinositol (Table 1). Menaquinones were
MK-9 $\left(\mathrm{H}_{6}\right) \quad(59 \%), \quad$ MK-9 $\left(\mathrm{H}_{8}\right) \quad(35 \%)$ and MK-9 $\left(\mathrm{H}_{4}\right)$ $(0.6 \%)$ for strain $3-46-\mathrm{b}(3)^{\mathrm{T}}$ and MK- $9\left(\mathrm{H}_{6}\right)(52 \%)$, MK9( $\left.\mathrm{H}_{4}\right)(22 \%)$, MK-9 $\left(\mathrm{H}_{8}\right)(22 \%)$ and MK-9 $\left(\mathrm{H}_{2}\right)(0.3 \%)$ for strain $3-45-\mathrm{a}(11)^{\mathrm{T}}$ (Table 1). Major fatty acids found in strain 3-46-b $(3)^{\mathrm{T}}$ were iso- $\mathrm{C}_{16: 0}(23.1 \%), \mathrm{C}_{17: 0}(14.6 \%)$, $\mathrm{C}_{16: 0}(9.5 \%), \mathrm{C}_{15: 0}(9.1 \%)$ and $\mathrm{C}_{17: 1} \omega 8 c(8.7 \%)$; minor amounts of 10-methyl $\mathrm{C}_{17: 0}(5.8 \%), \mathrm{C}_{18: 1} \omega 9 c(4.6 \%)$, $\mathrm{C}_{17: 1} \omega 9 c(4.3 \%)$, iso- $\mathrm{C}_{18: 0}(3.2 \%)$, iso- $\mathrm{C}_{14: 0}(3.0 \%), 10$ methyl $\mathrm{C}_{18: 0}$ [tuberculostearic acid (TBSA)] (2.4\%) and summed feature $6(2.3 \%)$ were also present. Major fatty acids for strain 3-45-a(11) ${ }^{\mathrm{T}}$ were iso- $\mathrm{C}_{16: 0}(24.0 \%), \mathrm{C}_{17: 0}$ $(14.7 \%), \mathrm{C}_{16: 0}(12.0 \%), \mathrm{C}_{17: 1} \omega 8 c(8.7 \%)$ and $\mathrm{C}_{15: 0}$ (8.1\%); minor amounts of 10-methyl $\mathrm{C}_{17: 0}(5.0 \%)$, $\mathrm{C}_{18: 1} \omega 9 c(4.8 \%)$, iso- $\mathrm{C}_{18: 0}(4.1 \%)$, iso- $\mathrm{C}_{14: 0}(4.0 \%)$, $\mathrm{C}_{18: 0}(2.3 \%)$, TBSA $(2.2 \%)$ and summed feature $6(2.3 \%)$ were also present (Table 1). These chemotaxonomic properties can be used to distinguish members of the genus Actinomadura from members of the genus Nonomuraea that form similar short chains of spores (Zhang et al., 1998, 2001; Quintana et al., 2003b; Ara et al., 2007a, b).

Table 1. Differential characteristics between strains $3-46-b(3)^{\top}$ and $3-45-a(11)^{\top}$ and the type strains of Actinomadura napierensis and Actinomadura meyerae

Data for reference strains were taken from Cook et al. (2005), Kroppenstedt et al. (1990), Kämpfer et al. (2005), Zhang et al. (1998), Poscher et al. (1985), Quintana et al. (2003a) and Trujillo \& Goodfellow (2003). +, Positive; \pm , moderate; -, negative; t, trace; ND, no data available.

\begin{tabular}{|c|c|c|c|c|}
\hline Characteristic & $3-46-b(3)^{T}$ & $3-45-a(11)^{T}$ & A. napierensis $\mathrm{B} \mathrm{O}^{\mathrm{T}}$ & A. meyerae $\mathrm{A}^{288^{\mathrm{T}}}$ \\
\hline Aerial mycelium & Present & Present & Present & Absent/rare \\
\hline Spore mass arrangement & Curved to hooked & Spiral & Spiral & Hooked \\
\hline Spore surface ornamentation & Rough & Rough & Smooth & Warty \\
\hline Number of spores & $4-8$ & $3-8$ & ND & $\mathrm{ND}$ \\
\hline $\begin{array}{l}\text { Diffusible pigment on ISP } \\
\text { medium } 7\end{array}$ & - & - & + (Faint blue $)$ & - \\
\hline Growth at $45^{\circ} \mathrm{C}$ & \pm & + & ND & + \\
\hline Polar lipids ${ }^{\star}$ & PG, PI & PG, PI & DPG, PI, PG & DPG, PI, PIMs \\
\hline Menaquinone(s) & $9\left(\mathrm{H}_{6}\right), 9\left(\mathrm{H}_{8}\right), 9\left(\mathrm{H}_{4}\right)$ & $9\left(\mathrm{H}_{6}\right), 9\left(\mathrm{H}_{4}\right), 9\left(\mathrm{H}_{8}\right), 9\left(\mathrm{H}_{2}\right)$ & ND & $9\left(\mathrm{H}_{6}\right)$ \\
\hline Major fatty acids (\%) & $\begin{array}{l}\text { iso- } C_{16: 0}(23.1), C_{17: 0} \\
\quad(14.6), C_{16: 0}(9.5)\end{array}$ & $\begin{array}{c}\text { iso- } \mathrm{C}_{16: 0}(24.0), \mathrm{C}_{17: 0}(14.7), \\
\mathrm{C}_{16: 0}(12.0)\end{array}$ & TBSA (36), $\mathrm{C}_{16: 0}(28)$ & $\mathrm{ND}$ \\
\hline Cell-wall sugars $\dagger$ & Mad (t), Gal, Glc, Man & Mad, Gal, Glc, Man, Rib & Gal, Glc, Mad, Man, Rha & Gal, Glc, Mad, Man, Rib \\
\hline DNA G $+C$ content $(\mathrm{mol} \%)$ & 70.27 & 72.43 & 70.0 & ND \\
\hline \multicolumn{5}{|l|}{ Utilization of: } \\
\hline L-Arabinose & \pm & + & + & + \\
\hline Cellobiose & + & + & ND & + \\
\hline D-Fructose & \pm & \pm & + & + \\
\hline Glycerol & \pm & + & + & ND \\
\hline myo-Inositol & - & - & - & ND \\
\hline Mannitol & \pm & \pm & + & $\mathrm{ND}$ \\
\hline D-Mannose & - & - & ND & + \\
\hline Raffinose & - & - & + & + \\
\hline Sucrose & \pm & + & + & ND \\
\hline D-Xylose & \pm & + & + & + \\
\hline
\end{tabular}

${ }^{\star}$ DPG, Diphosphatidylglycerol; PG, phosphatidylglycerol; PI, phosphatidylinositol; PIMs, PI mannosides.

†Gal, Galactose; Glc, glucose; Mad, madurose; Man, mannose; Rha, rhamnose; Rib, ribose. 
The novel organisms were aerobic, Gram-positive, nonacid-alcohol-fast, non-motile actinomycetes that formed extensively branched substrate mycelia that carried aerial hyphae, which differentiated into chains of spores. Strains $3-46-\mathrm{b}(3)^{\mathrm{T}}$ and $3-45-\mathrm{a}(11)^{\mathrm{T}}$ produced well-developed branched substrate and aerial mycelium and did not fragment into bacillary or coccoid elements (Fig. 2). Curved to hooked, short spore chains of strain 3-46$\mathrm{b}(3)^{\mathrm{T}}$ consisted of about four to eight non-motile spores with a rough surface that were borne directly on aerial mycelium singly or in small clusters (Fig. 2a). Spiral (one turn) spore chains for strain $3-45-\mathrm{a}(11)^{\mathrm{T}}$ consisted of three to eight non-motile spores with a rough surface that were borne directly on the aerial mycelium (Fig. 2b). The two strains had different cultural characteristics (Tables 1 and 2) and these properties also served to distinguish the strains from each other and from phylogenetically closely related species that were included in the survey.

It is apparent from Fig. 1 that strains $3-46-\mathrm{b}(3)^{\mathrm{T}}$ and 3-45$\mathrm{a}(11)^{\mathrm{T}}$ belong to a distinct phylogenetic group. 16S rRNA gene sequence similarity between strains $3-46-b(3)^{\mathrm{T}}$ and $3-45-\mathrm{a}(11)^{\mathrm{T}}$ was $99.1 \%$. The new isolates were closely associated with the type strains of Actinomadura meyerae (16S rRNA gene sequence similarity of 98.3-98.5\%) and

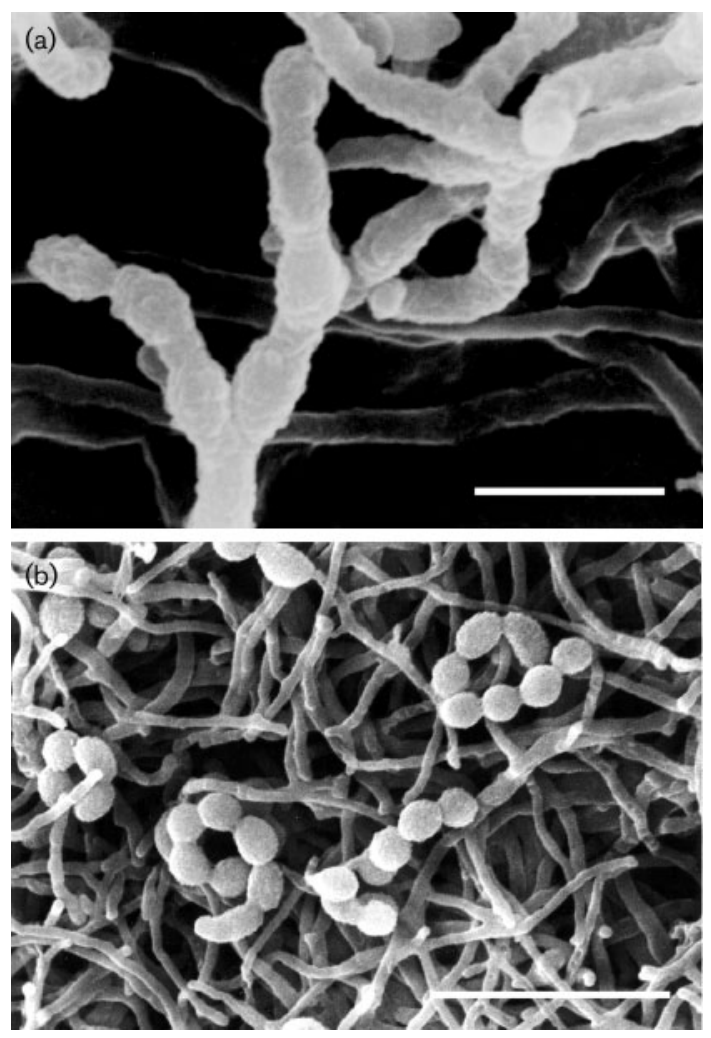

Fig. 2. Scanning electron micrographs of straight to curved spore chains on aerial mycelia of strains $3-46-b(3)^{\top}$ (a) and short spiral spore chains of strain $3-45-\mathrm{a}(11)^{\top}$ (b) grown on oatmeal agar at $30{ }^{\circ} \mathrm{C}$ for 3 weeks. Bars, $2 \mu \mathrm{m}$ (a), $5 \mu \mathrm{m}$ (b).
Actinomadura napierensis (98.1-98.3\%), although this relationship was not supported by a high bootstrap value (Fig. 1). Despite sharing relatively high 16S rRNA gene sequence similarities, the isolates could be distinguished from the type strains of their nearest phylogenetic neighbours, Actinomadura meyerae and Actinomadura napierensis, on the basis of spore ornamentation, pigment production on ISP medium 7, carbon source utilization, growth at $45{ }^{\circ} \mathrm{C}$ and polar lipids (Table 1). Furthermore, the level of DNA-DNA relatedness between the two new isolates was $43.6 \pm 2.3 \%$ (mean $\pm \mathrm{SD}$ from four determinations) and levels between the new isolates and the type strains of Actinomadura meyerae and Actinomadura napierensis were below $27 \%$, well below the $70 \%$ cut-off point recommended for the delineation of genomic species (Wayne et al., 1987).

It is clear from the genotypic and phenotypic data that strains $3-46-\mathrm{b}(3)^{\mathrm{T}}$ and $3-45-\mathrm{a}(11)^{\mathrm{T}}$ form a distinct clade within the genus Actinomadura. It is also evident from the phenetic and chemotaxonomic data that the two strains can be distinguished from each other and from the type strains of closely related species in the genus Actinomadura. In light of these data, it is proposed that strains $3-46-\mathrm{b}(3)^{\mathrm{T}}$ and $3-45-\mathrm{a}(11)^{\mathrm{T}}$ represent two novel species of the genus Actinomadura, for which the names Actinomadura bangladeshensis sp. nov. and Actinomadura chokoriensis sp. nov. are proposed.

\section{Description of Actinomadura bangladeshensis sp. nov.}

Actinomadura bangladeshensis (ban.gla.desh.en'sis. N.L. fem. adj. bangladeshensis pertaining to Bangladesh, where the type strain was isolated).

Forms a well-developed, branched substrate mycelium. Abundant aerial mycelium is present. Spore chains (four to eight spores) are curved to slightly hooked and spores are oval to cylindrical with a rough surface. Sporangia are not detected. Good growth occurs on ISP media 3, 4, 5 (glycerol-asparagine agar) and 7, glucose-yeast extract, Hickey-Tresner agar, Waksman agar and oatmeal-nitrate agar; moderate growth occurs on glucose-asparagine agar, yeast extract-malt extract agar and Bennett agar; and poor growth occurs on nutrient agar, water agar and Seino agar. Substrate mycelium colour is light wheat (2ea) to bamboo $(2 \mathrm{gc})$ on various agar media. Pale pink to white aerial mycelium and abundant sporulation are found on ISP media 3, 4 and 7, Hickey-Tresner agar, Waksman agar and oatmeal-nitrate agar after 21 days incubation at $28{ }^{\circ} \mathrm{C}$. Soluble pigment is not produced. Aerobic. Grampositive. Growth occurs at $\mathrm{pH}$ 5.0-9.0. The temperature range for growth is between 20 and $45{ }^{\circ} \mathrm{C}$. Production of melanoid pigments is negative. Good growth occurs with $4 \% \mathrm{NaCl}$. The isomer of DAP is meso, and madurose, galactose, glucose and mannose occur in whole-cell hydrolysates. The $\mathrm{N}$-acyl type of muramic acid is acetyl. Mycolic acids are absent. The polar lipids include 
Table 2. Differential cultural characteristics of strains $3-46-b(3)^{\top}$ and $3-45-a(11)^{\top}$

Cultures were incubated at $30{ }^{\circ} \mathrm{C}$ for 3 weeks. Diffusible pigments were not formed on any of the agar media tested. Colour designations and codes in parentheses were taken from Jacobson et al. (1958). Growth and sporulation on aerial mycelium were scored as: ++ , good; + , moderate; \pm , poor; -, no growth and no spores formed.

\begin{tabular}{|c|c|c|c|c|c|c|c|c|}
\hline \multirow[t]{2}{*}{ Agar medium } & \multicolumn{4}{|c|}{$3-46-b(3)^{T}$} & \multicolumn{4}{|c|}{$3-45-\mathrm{a}(11)^{\mathrm{T}}$} \\
\hline & Growth & Reverse colour & $\begin{array}{c}\text { Aerial } \\
\text { mycelium }\end{array}$ & Sporulation & Growth & Reverse colour & $\begin{array}{c}\text { Aerial } \\
\text { mycelium }\end{array}$ & Sporulation \\
\hline ISP medium 2 & + & Bamboo (2gc) & - & - & ++ & $\operatorname{Tan}(3 i c)$ & - & - \\
\hline ISP medium 3 & ++ & Bamboo $(2 g c)$ & + & ++ & ++ & Light wheat (2ea) & ++ & ++ \\
\hline ISP medium 4 & ++ & Light beige (3ec) & + & ++ & ++ & Shell $(3 \mathrm{ca})$ & \pm & \pm \\
\hline Bennett & + & Bamboo (2gc) & - & - & ++ & $\operatorname{Tan}(3 \mathrm{ic})$ & - & - \\
\hline Glucose-asparagine & + & Light ivory (2ca) & \pm & + & + & Flesh pink (4ca) & - & - \\
\hline Glucose-yeast extract & ++ & Honey gold (2ic) & - & - & ++ & Clove brown (3ni) & + & ++ \\
\hline Hickey-Tresner ${ }^{\star}$ & ++ & Light $\tan (3 g c)$ & + & ++ & ++ & Tan $(3 i c)$ & + & ++ \\
\hline Water & \pm & Colourless & + & + & \pm & Colourless & \pm & \pm \\
\hline Waksman & ++ & Colourless & + & ++ & ++ & Colourless & - & - \\
\hline
\end{tabular}

*Waksman (1961).

phosphatidylglycerol and phosphatidylinositol. The major menaquinone is MK-9 $\left(\mathrm{H}_{6}\right)$; minor amounts of MK-9 $\left(\mathrm{H}_{8}\right)$ and MK-9 $\left(\mathrm{H}_{4}\right)$ are found. Major fatty acids $(>8.0 \%$ of the total) are iso- $\mathrm{C}_{16: 0}, \mathrm{C}_{17: 0}, \mathrm{C}_{16: 0}, \mathrm{C}_{15: 0}$ and $\mathrm{C}_{17: 1} \omega 8 \mathrm{c}$. The $\mathrm{G}+\mathrm{C}$ content of the DNA of the type strain is $70.27 \mathrm{~mol} \%$.

The type strain, 3-46-b $(3)^{\mathrm{T}}\left(=\mathrm{JCM} 13933^{\mathrm{T}}=\mathrm{MTCC} 057^{\mathrm{T}}\right)$, was isolated from sandy soil of Chokoria, Cox's Bazar, Bangladesh.

\section{Description of Actinomadura chokoriensis sp. nov.}

Actinomadura chokoriensis (cho.ko.ri.en'sis. N.L. fem. adj. chokoriensis pertaining to Chokoria, Bangladesh, the origin of the soil from which the type strain was isolated).

Forms a well-developed, branched substrate mycelium. Abundant aerial mycelium is present. Spore chains are spiral with three to eight spores. Sporangia are not detected. Spores are spherical to oval and the spore surface is rough. Good growth occurs on ISP media 2, 3, 4, 5 and 7, Bennett agar, glucose-yeast extract agar, Hickey-Tresner agar, Waksman agar and oatmeal-nitrate agar; moderate growth occurs on glucose-asparagine agar, nutrient agar and Seino agar; and poor growth occurs on water agar. Substrate mycelium colour is light wheat (cream) (2ea) to clove brown (3ni) on various agar media. White aerial mycelium and sporulation are found on glycerol-asparagine, oatmeal agar, glucose-yeast extract, Hickey-Tresner agar, tap-water agar, oatmeal-nitrate and Seino agar media after 14 days incubation at $28{ }^{\circ} \mathrm{C}$. Soluble pigment is not produced. Aerobic. Gram-positive. Growth occurs at $\mathrm{pH}$ 5.0-9.0. The temperature range for growth is between 20 and $45{ }^{\circ} \mathrm{C}$. Production of melanoid pigments is negative. Good growth occurs with $4 \% \mathrm{NaCl}$. The isomer of DAP is meso, and madurose, galactose, glucose, mannose and ribose occur in whole-cell hydrolysates. The $\mathrm{N}$-acyl type of muramic acid is acetyl. Mycolic acids are absent. Polar lipids include phosphatidylglycerol and phosphatidylinositol. Phosphatidylcholine is absent. The major menaquinone is MK-9 $\left(\mathrm{H}_{6}\right)$; minor amounts of MK-9 $\left(\mathrm{H}_{4}\right)$ and MK-9 $\left(\mathrm{H}_{8}\right)$ are found. The fatty acid profile is characterized by the presence of significant amounts ( $>8.0 \%$ of the total) of iso- $\mathrm{C}_{16: 0}, \mathrm{C}_{17: 0}, \mathrm{C}_{16: 0}, \mathrm{C}_{17: 1} \omega 8 \mathrm{c}$ and $\mathrm{C}_{15: 0}$. The $\mathrm{G}+\mathrm{C}$ content of the DNA of the type strain is $72.43 \mathrm{~mol} \%$.

The type strain, 3-45-a $(11)^{\mathrm{T}}\left(=\mathrm{JCM} 13932^{\mathrm{T}}=\right.$ MTCC $\left.8056^{\mathrm{T}}\right)$, was isolated from sandy soil of Chokoria, Cox's Bazar, Bangladesh.

\section{Acknowledgements}

I. A. was supported by a research fellowship from the Institute for Fermentation, Osaka (IFO), Japan, and the Japan Society for the Promotion of Science (JSPS). 


\section{References}

Ara, I. \& Kudo, T. (2006). Three novel species of the genus Catellatospora, Catellatospora chokoriensis sp. nov., Catellatospora coxensis sp. nov. and Catellatospora bangladeshensis sp. nov. and transfer of Catellatospora citrea subsp. methionotrophica Asano and Kawamoto 1988 to Catellatospora methionotrophica sp. nov., comb. nov. Int J Syst Evol Microbiol 56, 393-400.

Ara, I. \& Kudo, T. (2007a). Two new species of the genus Micromonospora: Micromonospora chokoriensis sp. nov. and Micromonospora coxensis sp. nov., isolated from sandy soil. J Gen Appl Microbiol 53, 29-37.

Ara, I. \& Kudo, T. (2007b). Luedemannella gen. nov., a new genus of the family Micromonosporaceae, and description of Luedemannella helvata sp. nov. and Luedemannella flava sp. nov. J Gen Appl Microbiol 53, 39-51.

Ara, I. \& Kudo, T. (2007c). Krasilnikovia gen. nov., a new genus of the family Micromonosporaceae, and description of Krasilnikovia cinnamonea sp. nov. Actinomycetologica 21, 1-10.

Ara, I. \& Kudo, T. (2007d). Sphaerosporangium gen. nov., a new genus of the family Streptosporangiaceae, with descriptions of three new species as Sphaerosporangium melleum sp. nov., Sphaerosporangium rubeum sp. nov., Sphaerosporangium cinnabarinum sp. nov. and transfer of Streptosporangium viridialbum Nonomura and Ohara 1960 to Sphaerosporangium viridialbum comb. nov. Actinomycetologica 21, $11-21$.

Ara, I., Kudo, T., Matsumoto, A., Takahashi, Y. \& Omura, S. (2007a). Nonomuraea bangladeshensis sp. nov. and Nonomuraea coxensis sp. nov. Int J Syst Evol Microbiol 57, 1504-1509.

Ara, I., Kudo, T., Matsumoto, A., Takahashi, Y. \& Omura, S. (2007b). Nonomuraea maheshkhaliensis sp. nov., a novel actinomycete isolated from mangrove rhizosphere mud. J Gen Appl Microbiol 53, 159-166.

Asano, K. \& Kawamoto, I. (1986). Catellatospora, a new genus of the Actinomycetales. Int J Syst Bacteriol 36, 512-517.

Becker, B., Lechevalier, M. P. \& Lechevalier, H. A. (1965). Chemical composition of cell-wall preparation from strains of various formgenera of aerobic actinomycetes. Appl Microbiol 13, 236-243.

Collins, M. D., Pirouz, T., Goodfellow, M. \& Minnikin, D. E. (1977). Distribution of menaquinones in actinomycetes and corynebacteria. J Gen Microbiol 100, 221-230.

Collins, M. D., Faulkner, M. \& Keddie, R. M. (1984). Menaquinone composition of some spore forming actinomycetes. Syst Appl Microbiol 5, 20-29.

Cook, A. E., Le Roes, M. \& Meyers, P. R. (2005). Actinomadura napierensis sp. nov., isolated from soil in South Africa. Int J Syst Evol Microbiol 55, 703-706.

Couch, J. N. (1963). Some new genera and family of Actinoplanaceae. J Elisha Mitchell Sci Soc 79, 53-70.

Ezaki, T., Hashimoto, Y. \& Yabuuchi, E. (1989). Fluorometric deoxyribonucleic acid-deoxyribonucleic acid hybridization in microdilution wells as an alternative to membrane filter hybridization in which radioisotopes are used to determine genetic relatedness among bacterial strains. Int J Syst Bacteriol 39, 224-229.

Felsenstein, J. (1985). Confidence limits on phylogenies: an approach using the bootstrap. Evolution 39, 783-791.

Hayakawa, M. \& Nonomura, H. (1987). Humic acid-vitamin agar, a new medium for selective isolation of soil actinomycetes. J Ferment Technol 65, 501-509.

Henssen, A. (1957). Beitrage zur Morphologie und Systematik der thermophilen Actinomyceten. Arch Microbiol 26, 373-414 (in German). linuma, S., Yokota, A., Hasegawa, T. \& Kanamaru, T. (1994). Actinocorallia gen. nov., a new genus of the order Actinomycetales. Int J Syst Bacteriol 44, 230-234.

Itoh, T., Kudo, T., Parenti, F. \& Seino, A. (1989). Amended description of the genus Kineosporia, based on chemotaxonomic and morphological studies. Int J Syst Bacteriol 39, 168-173.

Jacobson, E., Grauville, W. C. \& Fogs, C. E. (1958). Color Harmony Manual, 4th edn. Chicago: Container Corporation of America.

Kämpfer, P., Kroppenstedt, R. M. \& Grun-Wollny, I. (2005). Actinomadura kuesteri sp. nov. Int J Syst Evol Microbiol 55, 847-851.

Kroppenstedt, R. M. \& Goodfellow, M. (1991). The family Thermomonosporaceae. In The Prokaryotes, 2nd edn, pp. 1085-1114. Edited by A. Balows, H. G. Trüper, M. Dworkin, W. Harder \& K. H. Schleifer. New York: Springer.

Kroppenstedt, R. M., Stackebrandt, E. \& Goodfellow, M. (1990). Taxonomic revision of the actinomycete genera Actinomadura and Microtetraspora. Syst Appl Microbiol 13, 148-160.

Le Roes, M. \& Meyers, P. R. (2007). Actinomadura rudentiformis sp. nov., isolated from soil. Int J Syst Evol Microbiol 57, 45-50.

Lechevalier, M. P. \& Lechevalier, H. A. (1970). Chemical composition as a criterion in the classification of aerobic actinomycetes. Int J Syst Bacteriol 20, 435-443.

Lee, S. D. (2006). Actinocorallia cavernae sp. nov., isolated from a natural cave in Jeju, Korea. Int J Syst Evol Microbiol 56, 1085-1088.

Lee, S. D. \& Jeong, H. S. (2006). Actinomadura hallensis sp. nov., a novel actinomycete isolated from Mt. Halla in Korea. Int J Syst Evol Microbiol 56, 259-264.

Lu, Z., Wang, L., Zhang, Y., Shi, Y., Liu, Z., Quintana, E. T. \& Goodfellow, M. (2003). Actinomadura catellatispora sp. nov. and Actinomadura glauciflava sp. nov., from a sewage ditch and soil in southern China. Int J Syst Evol Microbiol 53, 137-142.

Minnikin, D. E., O'Donnell, A. G., Goodfellow, M., Alderson, G., Athalye, M., Schaal, A. \& Parlett, J. H. (1984). An integrated procedure for the extraction of bacterial isoprenoid quinones and polar lipids. J Microbiol Methods 2, 233-241.

Nakajima, Y., Kitpreechavanich, V., Suzuki, K. \& Kudo, T. (1999). Microbispora corallina sp. nov., a new species of the genus Microbispora isolated from Thai soil. Int J Syst Bacteriol 49, 1761-1767.

Ochi, K., Miyadoh, S. \& Tamura, T. (1991). Polyacrylamide gel electrophoresis analysis of ribosomal protein AT-L30 as a novel approach to actinomycete taxonomy: application to the genera Actinomadura and Microtetraspora. Int J Syst Bacteriol 41, 234-239.

Poscher, J., Kroppenstedt, R. M., Fischer, A. \& Stackebrandt, E. (1985). DNA:DNA reassociation and chemotaxonomic studies on Actinomadura, Microbispora, Microtetraspora, Micropolyspora and Nocardiopsis. Syst Appl Microbiol 6, 264-270.

Quintana, E. T., Trujillo, M. E. \& Goodfellow, M. (2003a). Actinomadura mexicana sp. nov. and Actinomadura meyerae sp. nov., two novel soil sporoactinomycetes. Syst Appl Microbiol 26, 511517.

Quintana, E., Maldonado, L. \& Goodfellow, M. (2003b). Nonomurae terrinata sp. nov., a novel soil actinomycete. Antonie van Leeuwenhoek 84, 1-6.

Raeder, U. \& Broda, P. (1985). Rapid preparation of DNA from filamentous fungi. Lett Appl Microbiol 1, 17-20.

Saitou, N. \& Nei, M. (1987). The neighbor-joining method: a new method for reconstructing phylogenetic trees. Mol Biol Evol 4, 406-425.

Sasser, M. (1990). Identification of bacteria by gas chromatography of cellular fatty acids, MIDI Technical Note 101. Newark, DE: MIDI Inc. 
Shirling, E. B. \& Gottlieb, D. (1966). Methods for characterization of Streptomyces species. Int J Syst Bacteriol 16, 313-340.

Stackebrandt, E., Rainey, F. A. \& Ward-Rainey, N. L. (1997). Proposal for a new hierarchic classification system, Actinobacteria classis nov. Int J Syst Bacteriol 47, 479-491.

Staneck, J. L. \& Roberts, G. D. (1974). Simplified approach to identification of aerobic actinomycetes by thin-layer chromatography. Appl Microbiol 28, 226-231.

Stevenson, I. L. (1967). Utilization of aromatic hydrocarbons by Arthrobacter sp. Can J Microbiol 13, 205-211.

Tamaoka, J. \& Komagata, K. (1984). Determination of DNA base composition by reversed-phase high-performance liquid chromatography. FEMS Microbiol Lett 25, 125-128.

Tamaoka, J., Katayama-Fujimura, Y. \& Kuraishi, H. (1983). Analysis of bacterial menaquinone mixtures by high performance liquid chromatography. J Appl Bacteriol 54, 31-36.

Thompson, J. D., Gibson, T. J., Plewniak, F., Jeanmougin, F. \& Higgins, D. G. (1997). The CLUSTAL_X windows interface: flexible strategies for multiple sequence alignment aided by quality analysis tools. Nucleic Acids Res 25, 4876-4882.

Tomiyasu, I. (1982). Mycolic acid composition and thermally adaptive changes in Nocardia asteroides. J Bacteriol 151, 828-837.

Trujillo, M. E. \& Goodfellow, M. (1997). Polyphasic taxonomic study of clinically significant Actinomadura including the description of Actinomadura latina sp. nov. Zentralbl Bakteriol 285, 212-233.
Trujillo, M. E. \& Goodfellow, M. (2003). Numerical phenetic classification of clinically significant aerobic sporoactinomycetes and related organisms. Antonie van Leeuwenhoek 84, 39-68.

Uchida, K. \& Aida, K. (1984). An improved method for the glycolate test for simple identification of acyl type of bacterial cell walls. J Gen Appl Microbiol 30, 131-134.

Waksman, S. A. (1950). The Actinomycetes: Their Nature, Occurrence, Activities and Importance. Waltham, MA: Chronica Botanica.

Waksman, S. A. (1961). The Actinomycetes, vol. 2, Classification, Identification and Description of Genera and Species. Baltimore: Williams \& Wilkins.

Wayne, L. G., Brenner, D. J., Colwell, R. R., Grimont, P. A. D., Kandler, O., Krichevsky, M. I., Moore, L. H., Moore, W. E. C., Murray, R. G. E. \& other authors (1987). International Committee on Systematic Bacteriology. Report of the ad hoc committee on reconciliation of approaches to bacterial systematics. Int J Syst Bacteriol 37, 463-464.

Zhang, Z., Wang, Y. \& Ruan, J. (1998). Reclassification of Thermomonospora and Microtetraspora. Int J Syst Bacteriol 48, 411-422.

Zhang, Z., Kudo, T., Nakajima, Y. \& Wang, Y. (2001). Clarification of the relationship between the members of the family Thermomonosporaceae on the basis of 16S rDNA, 16S-23S rRNA internal transcribed spacer and $23 \mathrm{~S}$ rDNA sequences and chemotaxonomic analyses. Int J Syst Evol Microbiol 51, 373-383. 